\title{
高职院校 “互联网+”模式下党建工作创新的实践与探索
}

\author{
蒋亚莉 许蕴文 \\ 无锡工艺职业技术学院 \\ DOI:10.12238/mef.v3i8.2795
}

\begin{abstract}
[摘要] 随着科技的发展、社会的进步，互联网技术得到了全面普及，“互联网+”模式逐渐应用于社 会各个领域, 为社会的发展注入了新活力。高职院校党建工作作为高校建设和发展的重点工作之一, 我们应该基于 “互联网+” 模式下对党建工作的创新进一步研究和实践, 创建出新的党建模式。针对 高校党建工作的开展, 我们应该积极引进新的知识和技术, 优化高职院校党建发展模式, 充分发挥“互 联网+”的优势。本文就高职院校 “互联网+” 模式下党建工作创新进行研究分析, 并探索新的发展路 径, 促进高职院校党建工作的顺利开展。
\end{abstract}

[关键词] 高职院校; “互联网+”; 党建工作; 创新

中图分类号: G41 文献标识码: A

\section{Practice and Exploration of Party Building Work Innovation under the "Internet +" Mode in Higher Vocational Colleges \\ Yali Jiang, Yunwen Xu \\ Wuxi Vocational Institute of Arts \& Technology}

\begin{abstract}
[Abstract] With the development of science and technology and the progress of society, internet technology has been fully popularized, and the "internet +" model has gradually been applied to all fields of society, injecting new vitality into the development of society. The Party building work of higher vocational colleges is one of the key tasks of the construction and development of colleges and universities. We should further research and practice the innovation of Party building work under the "internet +" model, and create a new Party building model. For Party building in colleges and universities, we should actively introduce new knowledge and technology, optimize the development model of party building in vocational colleges, and give full play to the advantages of "internet +". This article conducts research and analysis on the innovation of Party building work under the "internet +" model of vocational colleges, and explores new development paths, so as to promote the smooth development of Party building work in vocational colleges.
\end{abstract}

[Key words] higher vocational colleges; "internet+"; Party building work; innovation

\section{1 “互联网+”模式下高职院校 党建工作的内涵 \\ “互联网+”是人们对互联网融入各} 个领域的形象定义, 互联网 + , 即互联网 + 行业, “互联网+” 模式下, 党建工作的 内涵在于人们利用互联网通信技术和互 联网平台, 将党建工作和互联网进行有 机整合, 充分发挥出互联网新技术的优 势, 为高职院校党建工作注入新活力。 新时代背景下, 高校教育工作和互联网 进行有机结合, 信息技术的融入, 可以
提高高职院校党建质量。党组织人员充 分利用互联网通信技术和互联网平台, 整合高校党建内容, 使信息数字化和网 络化, 促进党建知识、教育内容的传播, 打造党建特色品牌, 让师生更好的了解 到党建信息。

2 “互联网+” 模式下高职院校 党建工作模式的特征

2.1创新性

传统的党建工作开展, 大多采用参 观座谈、主题班会、纸质心得等等方式
进行, 由于传统的党建活动太过于单调, 无法激发师生的学习兴趣。采用 “互联 网 + ” 模式的党建工作, 可以很好利用先 进的科学技术, 对党建工作模式创新, 使师生通过电脑和手机在网上进行学 习, 人们也乐于用这种方法进行学习。 此外, 通过线上党建工作的开展, 方便 党建工作者与师生进行实时沟通交流, 工作开展上具有较高的创新性。

\section{2形象性}

传统党建活动, 采用的 “我教你学、 
我讲你听” 的工作模式, 这种传统的党 建工作模式由于受时间、空间上的限制， 已经无法完美发挥出党建的效果, 也无 法对高职院校积极分子进行教育和引 导。如果采用互联网模式, 则可以解决 这个难题。实行互联网+党建模式, 可以 充分利用先进的科技手段，将党建理论 性内容通过视频、图片、音乐、三维动 画、竞猜等等形式, 以更加丰富形象方 式呈现出来, 有利于师生更好理解。

\section{3实践性}

合理巧妙的运用互联网技术和平 台, 可以开放党建工作环境, 有利于师 生参与到党建活动实践当中。党建工作 者利用网络信息技术优势, 可以在任何 时段与不同工作对象进行面对面交流， 开展党建有关活动, 全方位打破传统的 时间、地点、空间上束缚, 延伸党建工 作的空间，有着较强的实践性。

\section{4示范性}

随着互联网技术的普及，网络已经 成为人们生活中的一部分, 网上的内容, 对学生思想也有着强大的冲击。互联网 与党建工作的融合, 党建工作人员可以 利用互联网平台进行思想引领, 通过加 强自身素养, 树立模范榜样, 通过互联 网达到示范性作用。

\section{3 目前高职院校党建工作存在 的困境}

3. 1 品牌意识单薄

随着科技的发展，互联网已经全球 化, 传统的党建工作模式已经不能够很 好满足现代化发展需要, 我们需要引用 先进的科技手段，进行党建工作上的创 新。但是, 就目前形势而言, 很多高职 院校并没有意识到互联网对党建工作的 重要性, 思想仍然比较传统, 缺乏对互 联网的认识。此外, 互联网平台需要涉 及到更新, 部分工作人员没有创新意识, 不能够建立起互联网+党建品牌, 品牌意 识比较薄弱。

\section{2 缺乏设计及规划}

随着互联网技术的高速发展、网络
的普及, 互联网平台信息呈现出丰富化、 复杂化、多样化发展。互联网平台丰富 的内容和信息, 如果不能够进行合理的 分类, 将会大大降低平台内容的可读性, 使师生失去学习兴趣。就目前高职院校 党建工作而言, 虽然很多高校都参与到 了互联网党建平台的建设中来, 但是, 在互联网党建工作开展中, 并没有充分 认识到平台设计的重要性, 这就导致很 多高职院校的互联网平台信息太过于复 杂繁多, 内容归类不合理, 缺少合理规 划, 导致师生学习积极性不高。平台板 块功能过少, 也是造成互联网党建工作 开展难的原因之一, 平台功能少, 建设 者未对平台进行有效挖掘利用, 人们获 取方式就会比较单一, 也就大大降低了 互联网平台的使用价值。

\section{3 缺乏特色与创新}

大众的网络审美水平一直在不断的 提高, 对网络平台界面的要求也越来越 高。但是, 很多高职院校党建互联网平 台界面过于单调乏味, 缺少特色, 不能 对学生视觉上带来冲击。宣传视频上, 缺少故事性演绎, 复杂繁多的理论语言, 让师生觉得学习枯燥无味, 抽象化的理 论知识也不利于人们更好的理解, 这些 都严重制约了党建工作的开展。平台在 使用过程中, 势必会出现各种各样的问 题, 很多学校缺乏对平台的管理和优化, 如果学校未对平台进行及时维护和创 新, 平台就跟不上信息发展的步伐, 将 会逐渐失去原有的价值和意义。

\section{4 评价机制不健全}

高职院校党建工作面向的主体是师 生, 党建工作考核的目的是激励基层党 员, 鞭策基层人员不断提高专业素养和 思想道德。但是, 有些高职院校的党建 工作评价机制不健全, 重点不突出, 在 党建互联网平台建设过程中存在形式主 义, 不注重实际成果, 仅仅为了完成工 作而完成工作, 这是懒政不作为的表现。 此外, 考核结果也缺乏一定的权威性, 考核评测结果运用不足, 考核过程中,
缺少针对性, 对于考核的内容过于抽象, 没有相应的考核标准。

4 创新互联网+模式下高职院 校党建工作的有效途径

4. 1 塑造基层党组织独特的品牌 形象

党建工作人员应该树立正确的互 联网思维, 充分意识到互联网为党建工 作带来的机遇和挑战, 应该在 “互联网 +”背景下, 坚持党建工作的正确的方 向, 提高自己互联网意识。对于互联网 平台建设上, 应该加大品牌建设力度, 不断优化平台内容, 加强主题宣传, 建 立起独特的品牌形象。互联网作为党建 工作的重要阵地, 应该加大马克思主义 和党的方针政策宣传, 抓住互联网发展 机遇, 加大党建工作创新力度。根据互 联网变化, 不断创新工作方法, 充分发 挥党建工作中互联网平台和互联网技 术优势。

4. 2 加强基层党组织学习活动的针 对性和有效性

党建工作的开展要具有针对性, 高 校党建工作要保证基层党组织学习活动 的有效性, 避免形式主义的发生。党建 活动必须突出工作重点, 精益求精, 如 此才能促进党建工作的有效开展。基于 互联网+党建模式下的创新, 党建活动需 要合理运用互联网平台, 通过平台创建 党建主题活动, 并建立起监督机制, 通 过监督管理机制, 对活动进展进行实时 跟踪, 保证活动结果的有效性。要不断 创新平台建设成果, 建立目标定位功能, 对活动对象进行学习情况分析, 促进党 建活动质量的提升。

4. 3 丰富基层党组织建设的载体与 方式

新时代背景下, 互联网发展尤为迅 速, 网络日新月异, 这就要求我们需要 及时跟上互联网发展步伐。高职院校党 建工作应该充分挖掘互联网优势, 丰富 基层党组织建设载体和方式, 充分利用 党建微博、公众号、自媒体平台、论坛 
等板块, 积极拓展党建工作开展路径。 党建互联网平台建设要符合高职院校教 书育人和党的目标任务, 要与党的理论 贴合, 帮助基层党组织人员树立正确的 思想道德观念, 从丰富的党建建设平台 和载体中, 不断探索党建工作科学策略。 加强互联网平台建设管理者的专业素养 培养，提高网络专业知识。高职院校应 该积极引进新型的科技人才, 加强对互 联网平台的运营和管理。由专业人士指 导, 培养党建工作者的互联网技术水平, 打造一支专业化的党建互联网建设团 队，提升党建工作质量。

4. 4充分利用互联网进行管理服务。 高职院校应该充分利用好互联网 平台和技术, 加强高职院校党建的管 理和监督, 完善管理体制, 提高党建 工作者工作意识。“互联网+”模式下 党建工作开展, 应该注重实际成果, 严格杜绝形式主义行为发生。党建工 作应该明确工作的重点, 互联网平台
建设和开展中, 应该明确工作任务, 突出工作重点。互联网平台内容上, 应该加大对内容的处理和研究, 突出 教育和宣传主题, 精益求精。高职院 校党建工作者应该营造良好的网上讨 论氛围, 引领网络與论, 朝着正确的 方向不断进步和发展。制定科学有效 的网站运营机制, 提升党建工作效率, 创新互联网平台管理服务方法, 不断 的促进高职院校健康发展。

\section{5 结束语}

随着社会科技力量不断提升, 互联 网模式下党建工作已经成为高职院校党 建发展必然趋势。高职院校 “互联网+” 模式下党建工作创新, 应该紧跟时代发 展步伐, 与时俱进, 精益求精。科学的 运用好互联网技术和平台, 创新工作方 法, 注重平台质量的提升, 充分彰显互 联网+党建的优势。同时, 应该注重党建 工作者互联网技术和思维的提升, 在党 建工作开展中, 有效管理运营好互联网
平台, 在工作中突出重点, 进而促进我 国高职院校健康长远发展。

\section{基金项目:}

2020年无锡工艺职业技术学院党建 与思想政治研究会课题：互联网+背景 下高校基层党建工作品牌化建设的探索 与实践 (Djsz202006)。

[参考文献]

[1]赵瑞希,李爱华."互联网+"高校 党建工作模式的路径优化 [J]. 学理 论,2020(09):113-114.

[2]张捷."互联网+"背景下高校党建 融合路径分析 [J]. 湖北开放职业学院学 报,2020,33(14):114-115.

[3]王小伟.高职院校基层党建工 作实效性的思考 [J]. 现代教育论 坛,2020(03):1-2.

\section{作者简介:}

蒋亚莉 (1986--), 女, 汉族, 江苏如 东人, 助理研究员, 硕士, 研究方向: 教育管理。 